\title{
American Women Mathematics PhDs of the 1940s
}

\section{Margaret A. M. Murray}

\section{Introduction}

Since 1993, I have been compiling and updating a database of information on 192 women awarded PhDs in mathematics by institutions of higher education in the United States and Canada during the years 1940-1959. Back in the 1990s, I compiled the list using several print sources (see [15, pp. 21-23] for details) and, in subsequent years, I've crosschecked, augmented, and updated it against a number of online sources (e.g., departmental histories, official university publications, public documents available on genealogy websites, online obituaries). While it's difficult to be sure that the list of doctoral recipients is $100 \%$ complete, the total number for the US is reasonably close to that reported by the National Academy of Sciences (e.g., [9]). Since 2016, I've been gradually publishing information from the database at the Women Becoming Mathematicians website, WomenBecomingMathematicians .net([17]).

My work on both the database and the website is part of the larger project of clearly and accurately documenting the lives and careers of the first several generations of American women to earn PhDs in mathematics ([16]). The most substantial contribution to this work to date is that of Judy Green and Jeanne LaDuke who, in their book Pioneering Women in American Mathematics, provide detailed information on the first 228 American women who earned mathematics PhDs prior to 1940 ([7] and [8]). While my work does not approach the exhaustive detail of Green and LaDuke, it is my fervent hope that others will use these documentary resources as the foundation for future historical research.

Margaret A. M. Murray is an associate professor of instruction in the departments of rhetoric and mathematics at the University of Iowa. Her email address is margaret-a-murray@uiowa.edu.

Communicated by Notices Associate Editor Della Dumbaugh.

For permission to reprint this article, please contact: reprint-permission aams.org.

DOI: https://dx.doi.org/10.1090/noti2240
In this article, my specific focus is on the American women mathematics PhDs of the 1940s. I begin by laying out some historical context for understanding this cohort of American women in mathematics. Next, I provide a list (current as of January 2021) of the 86 women I've been able to identify who earned mathematics PhDs in the US and Canada during the 1940s, and go on to describe some of their personal and professional characteristics. Finally, I discuss ongoing work on the Women Becoming Mathematicians website ([17]), which serves as a reference repository for basic background information on this generation of American women mathematics PhDs.

A brief comment on notation: when I introduce a particular woman mathematics PhD in the text, I enclose the name of the PhD-granting institution and the year the $\mathrm{PhD}$ was awarded in parentheses immediately following the woman's name.

\section{Historical Context}

Across eras, civilizations, and cultures, it is clear that both women and men have carried out mathematical work. But in the recorded history of mathematics, there are very few accounts of women's mathematical activity before the 19th century. The 19th century also marks the emergence of the research doctoral degree, beginning in Europe and then spreading to America and across the globe. In most of the emerging mathematical communities of the late 19th and early 20th centuries, the PhD in mathematics came to be viewed as a certification of accomplishment in research and as prerequisite for admission to the professional caste in research mathematics ([18], [15, pp. 1-3]).

So far as we know, Sonya Kovalevskaya was the first woman to earn a PhD in mathematics, awarded to her in absentia by the University of Berlin in 1874 ([13, p. 123]). In 1862, Yale University awarded the first US PhD in mathematics-to a man, J. H. Worrall ([18, p. 202]). Twenty years later, in 1882, Christine Ladd-Franklin became the 
first woman to earn a PhD in mathematics from a US institution, Johns Hopkins University—but, famously, Hopkins refused to actually award her the degree until 1926 ([7, p. 5]). Thus Columbia University was the first US institution to actually award a $\mathrm{PhD}$ in mathematics to a woman, Winifred Edgerton Merrill, in 1886; she was, in fact, the first American woman awarded a $\mathrm{PhD}$ in mathematics anywhere, and the first woman to be awarded a Columbia degree of any kind ([7, p. 10, pp. 246-247], [11]).

Over the three decades that followed (1890-1919), women earned an increasing share of US PhDs in mathematics, approaching $14 \%$ of the total in the decade immediately prior to the ratification of the 19th Amendment to the US Constitution (granting women the right to vote). Over the following two decades (1920-1939), women's share of US mathematics PhDs leveled off but nevertheless remained fairly steady at just over $14 \%$ ([15, pp. 4-5]). But during the 1940s, the proportion of US mathematics doctorates earned by women began a precipitous decline; indeed, it was not until the 1980s that the proportion of US mathematics PhDs awarded to women attained and finally surpassed pre-World War II levels ([15, pp. 5-6], [7, pp. 113-115]).

Numerous social and political factors, both internal and external to the mathematical community, help to explain the puzzling decline and slow rebound of American women's participation in doctoral-level mathematics from the 1940 s to the 1980s. An account of these factors-including the postwar backlash against women's work outside the home, retrenchment in the American mathematical community, and the resurgence of the women's movement-makes for illuminating and cautionary reading, and gives the lie to the myth that continuous progress is possible for women in STEM ([15], [19], [20], [21]). Because they coincided with these years of tumultuous change in American society, the lives and careers of the women who earned mathematics PhDs in the 1940s (and 1950s) are a fascinating subject of study. And the women PhDs of the 1940s are of particular interest, having launched their careers in the transition between the relatively slow and steady growth in the American mathematical community prior to World War II and the period of explosive growth in that community—and in academia more generally_during the postwar period.

\section{The List}

Tables 1 and 2 below list the 86 American women mathematics PhDs of the 1940s. For each woman, I've provided the year in which her doctorate was awarded, the most complete version of her name that I've been able to identify, her years of birth and death, and the institution from which she earned the PhD. As of January 2021, five of the 86 women are still living; all are over the age of 95. One of these, Domina Eberle Spencer (MIT 1942), received her doctorate just shy of her 22nd birthday-the youngest degree recipient among the forties women-and has recently celebrated her 100th birthday. Among those who have died, three lived past age 100: Janet McDonald (Chicago 1943) and Sister M. Francis Borgia Stauder SSND (Notre Dame 1947) lived to 101, while Esther Seiden (California/Berkeley 1949) lived to 106. On the whole, this is a long-lived group, with an average lifespan well into the 80s.

A quick scan of the tables reveals several familiar names. Proceeding chronologically through the years 1940-1942, we first encounter Dorothy Maharam Stone (Bryn Mawr 1940) - a student of Anna Johnson Pell Wheeler (Chicago 1910) - well known for her research in measure theory and ergodic theory, with an Erdős number of 2. We also encounter Josephine Margaret Mitchell (Bryn Mawr 1942)_also a student of a well-known woman mathematician, Hilda Geiringer (Vienna 1917) — notable for her research in several complex variables. With her spouse, the mathematician Lowell I. Schoenfeld, Mitchell made a major bequest to the American Mathematical Society ([2]). And finally, we come to Alice Elizabeth Turner Schafer (Chicago 1942), who wrote a dissertation in projective differential geometry under Ernest P. Lane. Schafer held teaching positions at eight different colleges and universities, most notably Connecticut College and Wellesley College. But she is best known for her untiring advocacy on behalf of girls and women in mathematics, and for her indispensable role in establishing the Association for Women in Mathematics (AWM).

Continuing chronologically, we come to Euphemia Lofton Haynes (Catholic 1943), the first African-American woman to earn a $\mathrm{PhD}$ in mathematics. She earned her degree under Aubrey F. Landry, who supervised the theses of 28 students at Catholic University, 18 of whom were women ([7, p. 52]). Haynes devoted her career, both before and after the doctorate, to teaching in the public school system of Washington, DC, including several years at what is now the University of the District of Columbia (see [12]). Just 18 years earlier, Elbert Frank Cox had been the first African-American man to earn a mathematics $\mathrm{PhD}$; working under the direction of William Lloyd Garrison Williams, he received his degree from Cornell in 1925 ([22]). Somewhat later in the 1940s, Evelyn Boyd Granville (Yale 1949) became the second African-American woman to earn a mathematics PhD. After completing a dissertation in complex analysis with Einar Hille, she went on to a wide-ranging career spanning academia, government, and industry. Shortly thereafter, Marjorie Lee Browne (Michigan 1950) became the third African-American woman to earn a mathematics PhD, working with George Rainich. Although Browne's name does not appear in the forties list-her doctorate was awarded in 1950-she had completed all the requirements for the degree by the end of 1949 . 
Many other names in this list will be familiar to readers of the Notices. Mary Patricia Dolciani Halloran (Cornell 1947), known professionally as Mary Dolciani, was a prominent figure in mid-20th century American mathematics education. She earned her PhD in algebra and number theory under Burton W. Jones and went on to a long career at Hunter College. In 1974, Dr. Dolciani made a gift to the MAA to endow the Dolciani Mathematical Expositions series, now published by the AMS ([14]). Another endowment from the Mary P. Dolciani Halloran foundation funds the AMS Mary P. Dolciani Prize for Excellence in Research ([3]).

A doctoral student of the logician Alfred Tarski, Julia Bowman Robinson (California/Berkeley 1948) is well known as the first woman elected to the Mathematics section of the National Academy of Sciences; she earned this honor in 1976 as a result of her work in mathematical logic, specifically the resolution of Hilbert's Tenth Problem. She was also the first woman elected President of the AMS. Jane Smiley Cronin Scanlon (Michigan 1949), a distinguished applied mathematician and student of Erich Rothe, spent much of her career on the faculty at Rutgers and was recently memorialized in the pages of the Notices ([1]). And Mary Ellen Rudin (Texas 1949), perhaps the best-known student of R. L. Moore, had a distinguished career in teaching (mainly at the University of Wisconsin), service to the profession, and research in general topology; her Erdős number is 1 ([4]).

\section{Group and Individual Characteristics}

While some characteristics of the women PhDs of the 1940 s-both as a group and as individuals-emerge from examining the table, others require a deeper dive into the database. I highlight just a few of these characteristics here.

A total of 28 schools are represented among the degree-granting institutions. The top grantor of mathematics PhDs to women in the 1940s was the University of Illinois (9), followed by Catholic University of America (8), the University of Michigan (8), Radcliffe College (7), the University of Chicago (6), the University of California at Berkeley (6), and Cornell University (4). From 1902 to 1962, women could earn PhDs from Radcliffe College, the women's coordinate college of Harvard University, but not from Harvard itself ([10]). In every way but name, however, these were Harvard PhDs, so for each such degree I have designated the degree-granting institution as Harvard/ Radcliffe.

Fifteen of the 1940s PhDs listed are Roman Catholic sisters, more commonly referred to as nuns. (The letters that appear after their names signify the religious orders to which they belong; for example, the Missionary Sisters Servants of the Holy Spirit, also known as Servae Spiritus Sanctae, are denoted SSpS). Prior to 1940, a total of 18 Catholic sisters earned mathematics PhDs in the United
States, 17 of whom received the degree during the years 1929-1939, as part of an ongoing effort to "upgrade the level of instruction in Catholic women's colleges" ([7, p. 62]). This effort continued into the 1940s, and helps to explain the continued prominence of Catholic University as a grantor of mathematics PhDs to women during this decade. Because these Catholic sisters were typically already employed on college faculties before beginning graduate study, they earned their doctorates at a somewhat older-than-average age. And, as Green and LaDuke have observed, they generally did not have to seek out employment; their teaching assignments came directly from their religious orders ([7, p. 62]).

The list includes three mathematicians born in Canada. Jeanne Starrett LeCaine Agnew (Harvard/Radcliffe 1941) was born in Port Arthur, Ontario, received bachelor's and master's degrees from Queen's University in Kingston, Ontario, and earned her PhD under the direction of George D. Birkhoff. During the war, she worked for the National Research Council of Canada (NRC); during the postwar years, she enjoyed a decades-long career at Oklahoma State University. Josephine Mitchell, mentioned previously, was born in Edmonton, Alberta, and earned her undergraduate degree at the University of Alberta before coming to Bryn Mawr. Upon receiving the $\mathrm{PhD}$, Mitchell taught at nine different colleges and universities and worked in two private research labs before settling, at last, into a tenured full professorship at SUNY Buffalo. And Kathleen E. Butcher Whitehead (Michigan 1946), born in Shelburne, Ontario, earned her undergraduate degree at Queen's before coming to the US for graduate study, first at Smith College and then at Michigan. She held a succession of faculty positions in New England, culminating in 26 years on the mathematics faculty at Tufts.

The list also includes just one PhD awarded by a Canadian university, that of Muriel Kennett Wales (Toronto 1941). She was born in Belfast but moved to Vancouver while still in infancy; she earned bachelor's and master's degrees at the University of British Columbia. Wales' PhD appears to be both the fourth mathematics PhD awarded to a woman by a Canadian university and the fourth awarded by the University of Toronto-the first having been awarded to Cypra Cecilia Krieger in 1930. Like Jeanne Agnew, Wales worked for the NRC during the war years, first in Toronto and then in Montreal, but she appears to have withdrawn from mathematics after 1949. I'm indebted to Colm Mulcahy, who has a deep professional interest in the biographies of Irish mathematicians, for his assistance in tracking down the details of Wales' life and work.

A large majority of the women who earned a mathematics PhD from US institutions in the 1940s enjoyed long careers in education, mainly at the postsecondary level. There were, however, some noteworthy exceptions. A few taught extensively at the secondary level, including Euphemia 
Lofton Haynes, Sister Ingonda Maria von Mezynski SSpS (Marquette 1944), who taught secondary school in both the US and in Germany, and Margaret Ellen Stump Matchett (Indiana 1946), a student of Emil Artin, who taught at the University of Chicago Laboratory School ([6]).

Some individuals devoted much of their careers to academic administration, most notably Jean Brosius Walton (Pennsylvania 1948), who wrote her dissertation in number theory with Hans Rademacher after serving as an assistant dean at Swarthmore. Upon graduation, Walton faced a choice: should she return to administration, or pursue a career in mathematics teaching and research? Ultimately, she chose administration, serving as dean of women, and later dean of students, at Pomona College ([15, p. 198]). In addition, some of the Catholic sisters were called upon to serve as administrators of the colleges that employed them, continuing a pattern observed by Green and LaDuke among the PhDs of the 1930s ([7, p. 63]). For example, Sister Rose Gertrude Calloway CSJ (Catholic 1948) served as dean of residential students, academic dean, and president of Mt. St. Mary's College in California.

In a deviation from the pattern of pre-1940 PhDs, some of the 1940s women worked, at least for a time, entirely outside of teaching. Mary Dean Clement (Chicago 1941), a student of E. P. Lane, taught mathematics at Wells College, the University of Miami, Northwestern, and Chicago before joining the staff of the Chicago's Institute for Air Weapons research, where she spent most of the rest of her career. Ruth Eileen O'Donnell Goodman (Pennsylvania 1944)-like Jean Walton a student of Rademacher-began her career teaching at Syracuse, Queens College, and Duquesne before moving on to the Westinghouse Labs. Madeline Mary Johnsen Alexander (Stanford 1946), who wrote a dissertation in probability under George Pólya, taught at Purdue and the University of Delaware before moving to industry, where she worked for North American Rockwell and TRW. Frances Renee Brand Bauer (Brown 1948), a student of the applied mathematician Willy Prager, worked first for the defense contractor Reeves Instrument Corporation and then moved to the research staff at the Courant Institute of NYU. Bauer's career at Courant, where she collaborated with Paul Garabedian, spanned nearly half a century ([5]). And, during the 1950s and early 1960s, finding academia an inhospitable place for Black women, Evelyn Boyd Granville worked for the Army, IBM, and a number of private companies associated with the space program. She ultimately returned to teaching in 1967, first at Cal State Los Angeles, then at Texas College, and finally at the University of Texas at Tyler, from which she definitively retired in 1997.

To varying degrees, many of the forties women PhDsespecially those who remained in academia-pursued mathematical research after the doctorate. Among those already mentioned, Domina Spencer, Esther Seiden,
Dorothy Maharam Stone, Josephine Mitchell, Julia Robinson, Jane Cronin Scanlon, Mary Ellen Rudin, and Frances Bauer had extensive research careers. To these could be added the names of Christine S. Williams Ayoub (Yale 1947), Yael Naim Dowker (Harvard/Radcliffe 1948), and more. Still others achieved a satisfying balance between teaching and scholarship that I've described elsewhere using the term scholar-teacher [15, p. 44]. Among those for whom this description seems especially apt are Marion Dell Wetzel (Northwestern 1943), Winifred Alice Asprey (Iowa 1945), Grace Elizabeth Bates (Illinois 1946), Mary Dolciani, Margaret Frances Willerding (St. Louis 1947), and Helen Kelsall Nickerson (Harvard/Radcliffe 1949). The individuals named are intended as examples only, and are in no way meant to constitute an exhaustive list.

In general, the lives and careers of these 86 American women PhDs reflect the social, economic, and political transitions of World War II and the postwar period. In my previous work ([15]), I've examined the lives of 17 of them in considerable depth and detail; profiles of many more are scattered throughout the literature and across the web. But in my view, all 86 of them are worthy of much deeper, more careful, and more systematic study.

\section{The Women Becoming Mathematicians Website}

As of early January 2021, the Women Becoming Mathematicians website ([17]) provides very basic biographical information on 86 women PhDs of the 1940s-as well as 106 women PhDs of the 1950s (who are worthy of detailed consideration in their own right). Each woman in the database has her own dedicated page, which currently includes the following basic information: her date and place of birth (and death, if applicable), her undergraduate and graduate institutions and degrees earned, the name of her doctoral adviser, and her place of primary employment. Beginning in spring 2021, I will supplement this with additional information from the database, which currently exists as two Word text files and two sortable Excel spreadsheets. The current plan is to provide each individual's supplementary data as a pdf that can be viewed or downloaded from the webpage. While the data varies from person to person in its level of depth and detail, the sources of the information are all fully documented, and that source documentation will soon be readily available at the site.

I mean for the website to be a (hopefully permanent) repository for information from the database. In addition, I have a host of other documents-paper and electronic; text, image, and audio-which I plan to donate, sometime in the near future, to an appropriate repository. My goal is to make these items as accessible to scholars as possible. Ideally, I'd like these materials to reside among both the physical and the digital collections of the Archives of American Mathematics at the Dolph Briscoe Center for American History of the University of Texas at Austin. 
Each year in my History of Mathematics classes, I meet a new group of students who know very little about the history of women in mathematics. Ultimately, my goal is to ensure that the history of American women in mathematics, at least, is not lost. The website, the database, and the accompanying materials constitute just one small but significant step toward meeting this goal.

\section{References}

[1] Edward F. Aboufadel, In memoriam: Jane Smiley Cronin Scanlon, Notices Amer. Math. Soc. 66 (2019), no. 9, 14481452. MR3967936

[2] American Mathematical Society, Josephine M. Mitchell and Lowell I. Schoenfeld Gardens Dedication, Notices Amer. Math. Soc. 50 (2003), no. 8, 943.

[3] American Mathematical Society, 2019 Mary P. Dolciani Prize for Excellence in Research, Notices Amer. Math. Soc. 66 (2019), no. 4, 599-600.

[4] Georgia Benkart, Mirna Džamonja, and Judith Roitman (eds.), Memories of Mary Ellen Rudin, Notices Amer. Math. Soc. 62 (2015), no. 6, 617-629, DOI 10.1090/noti1254. MR3362445

[5] Philip Davis and Paul Garabedian, An interview with Paul Garabedian, Society for Industrial and Applied Mathematics and Computer History Museum, 2005, history. siam .org/pdfs2/Garabedian_final.pdf. Accessed 4 June 2020.

[6] Della Dumbaugh and Joachim Schwermer, Käte Hey and Margaret Matchett-two women PhD students of Emil Artin, Women in mathematics, Assoc. Women Math. Ser., vol. 10, Springer, Cham, 2017, pp. 51-66, DOI 10.1007/978-3319-66694-5_3. MR3775372

[7] Judy Green and Jeanne LaDuke, Pioneering women in American mathematics: The pre-1940 PhDs, History of Mathematics, vol. 34, American Mathematical Society, Providence, RI; London Mathematical Society, London, 2009. MR2464022

[8] Judy Green and Jeanne LaDuke, Supplementary material for Pioneering women in American mathematics: The pre-1940 PhDs, last updated 13 January 2016, https:// www.ams.org/publications/authors/books/postpub /hmath-34-PioneeringWomen . pdf Accessed 3 June 2020.

[9] Lindsey R. Harmon and Herbert Soldz (compilers), Doctorate production in United States Universities 1920-1962, National Academy of Sciences/National Research Council, Washington DC, 1963.

[10] Harvard Graduate School of Arts and Sciences, History, 2019, https://gsas.harvard.edu/about/history. Accessed 6 June 2020.

[11] Susan E. Kelly and Sarah A. Rozner, Winifred Edgerton Merrill: "She opened the door", Notices Amer. Math. Soc. 59 (2012), no. 4, 504-521, DOI 10.1090/noti818. MR2951954

[12] Susan E. Kelly, Carly Shinners, and Katherine Zoroufy, Euphemia Lofton Haynes: Bringing education closer to the "goal of perfection", Notices Amer. Math. Soc. 64 (2017), no. 9, 995-1003, DOI 10.1090/noti1579. MR3699774

[13] Ann Hibner Koblitz, A convergence of lives: Sofia Kovalevskaya: scientist, writer, revolutionary, 2nd ed., Lives of Women in Science, Rutgers University Press, New Brunswick, NJ, 1993. MR1317347
[14] Mathematical Association of America, Announcement of the Dolciani Mathematical Expositions, Amer. Math. Monthly 81 (1974), 562-563.

[15] Margaret A. M. Murray, Women becoming mathematicians: Creating a professional identity in post-World War II America, MIT Press, Cambridge, MA, 2000. MR1778333

[16] Margaret A. M. Murray, Toward a documentary history of American women mathematics PhDs: The doctoral classes of 1940-1959, Women in mathematics, Assoc. Women Math. Ser., vol. 10, Springer, Cham, 2017, pp. 91-101, DOI 10.1007/978-3-319-66694-5_5. MR3775374

[17] Margaret A. M. Murray, Women becoming mathematicians: American women mathematics PhDs 1940-1959, 2020, https://womenbecomingmathematicians.net.

[18] R. G. D. Richardson, The Ph.D. Degree and Mathematical Research, Amer. Math. Monthly 43 (1936), no. 4, 199-215, DOI 0.2307/2300615. MR1523632

[19] Margaret W. Rossiter, Women scientists in America, Volume 1: Struggles and strategies to 1940, Johns Hopkins University Press, Baltimore, 1982.

[20] Margaret W. Rossiter, Women scientists in America, Volume 2: Before affirmative action, Johns Hopkins University Press, Baltimore, 1995.

[21] Margaret W. Rossiter, Women scientists in America, Volume 3: Forging a new world since 1972, Johns Hopkins University Press, Baltimore, 2013.

[22] Talitha M. Washington, Evansville honors the first black Ph.D. in mathematics and his family, Notices Amer. Math. Soc. 55 (2008), no. 5, 588-589. MR2404031

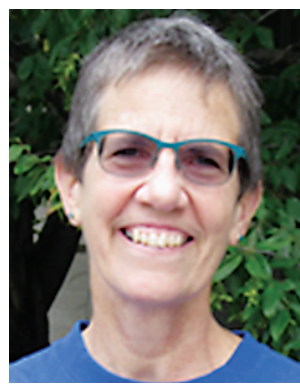

Margaret A. M. Murray

\section{Credits}

Author photo is courtesy of Douglas Slauson. 
HISTORY

Table 1. Women Mathematics PhDs from US \& Canadian institutions, 1940-1944

\begin{tabular}{|c|c|c|}
\hline Year & Name & PhD-granting institution \\
\hline \multirow{5}{*}{$\begin{array}{c}1940 \\
(5)\end{array}$} & Sister Elisabeth Frisch OSB (1901-1993) & Catholic \\
\hline & Katharine Elizabeth Hazard (1915-1992) & Chicago \\
\hline & Dorothy Maharam Stone (1917-2014) & Bryn Mawr \\
\hline & Edith Ruth Schneckenburger (1908-1990) & Michigan \\
\hline & (Orla) Virginia Wood Wakerling (1915-1997) & California/Berkeley \\
\hline \multirow{11}{*}{$\begin{array}{c}1941 \\
(11)\end{array}$} & Jeanne Starrett LeCaine Agnew (1917-2000) & Harvard/Radcliffe \\
\hline & Elizabeth Sherman Arnold (1915-1992) & California/Berkeley \\
\hline & Ethel Beatrice Callahan (1890-1983) & Columbia \\
\hline & Mary Dean Clement (1914-2005) & Chicago \\
\hline & (Jessie) Esther Comegys (1898-1990) & Harvard/Radcliffe \\
\hline & Margaret Mary Hansman (1911-2001) & Illinois \\
\hline & Harlan Cross Miller (1896-1981) & Texas \\
\hline & Sister Mary Jeannette Obrist OSB (1901-1985) & Catholic \\
\hline & Lois Kiefer Pedigo (1915-2009) & Illinois \\
\hline & Muriel Kennett Wales (1913-2009) & Toronto \\
\hline & Rhoda Manning Wood (1912-2006) & Stanford \\
\hline \multirow{9}{*}{$\begin{array}{c}1942 \\
(9)\end{array}$} & Claire B. Fischer Adler (1895-1990) & NYU \\
\hline & Sister St. Augustine Ball SSMN (1909-2004) & Catholic \\
\hline & Aughtum Luciel Smith Howard (1906-1994) & Kentucky \\
\hline & Josephine Margaret Mitchell (1912-2000) & Bryn Mawr \\
\hline & Anne Frances O’Neill (1915-2003) & Harvard/Radcliffe \\
\hline & Sister Mary de Pazzi Rochford OSF (1897-1984) & Notre Dame \\
\hline & Alice Elizabeth Turner Schafer (1915-2009) & Chicago \\
\hline & Mary Elizabeth Ladue Solari (1914-1986) & Columbia \\
\hline & Domina Eberle Spencer (1920- ) & MIT \\
\hline \multirow{8}{*}{$\begin{array}{c}1943 \\
(8)\end{array}$} & Anne Louise Lewis Anderson (1919-2010) & Chicago \\
\hline & Helen Pearl Beard (1915-2004) & MIT \\
\hline & Janie Campbell Lapsley Bell (1913-2010) & Illinois \\
\hline & Angeline Jane Brandt (1906-1968) & Michigan \\
\hline & (Martha) Euphemia Lofton Haynes (1890-1980) & Catholic \\
\hline & Janet McDonald (1905-2006) & Chicago \\
\hline & Sister Mary Philip Steele OP (1905-1979) & Catholic \\
\hline & Marion Dell Wetzel (1919-2012) & Northwestern \\
\hline \multirow{9}{*}{$\begin{array}{c}1944 \\
(9)\end{array}$} & Ruth Eileen O'Donnell Goodman (1917-2005) & Pennsylvania \\
\hline & Ida Roettinger Kaplan (1913-2005) & Michigan \\
\hline & Jennie Pasternak Kormes (1899-1992) & NYU \\
\hline & Margaret Pearl Martin (1915-2012) & Minnesota \\
\hline & Sister Joanne (Ethel Cecilia) Muggli OSB (1908-1987) & Washington (Seattle) \\
\hline & Mary Kent Peabody (1917-1991) & Yale \\
\hline & Ella Carolyn Marth Snader (1909-1978) & St. Louis \\
\hline & Sister Ingonda Maria von Mezynski SSpS (1911-2009) & Marquette \\
\hline & Sister Mary Claudia Zeller OSF (1910-1991) & Michigan \\
\hline
\end{tabular}


Table 2. Women Mathematics PhDs from US \& Canadian institutions, 1945-1949

\begin{tabular}{|c|c|c|}
\hline Year & Name & PhD-granting institution \\
\hline \multirow{5}{*}{$\begin{array}{c}1945 \\
(5)\end{array}$} & Frances Louise Campbell (Hinds) Amemiya (1913-1999) & Michigan \\
\hline & Winifred Alice ("Tim") Asprey (1917-2007) & Iowa \\
\hline & Miriam Clough Ayer (1912-1972) & Ohio State \\
\hline & (Bertha) Evelyn Frank (1908-1982) & Northwestern \\
\hline & Corinne Rose Hattan (1903-1964) & Illinois \\
\hline \multirow{9}{*}{$\begin{array}{c}1946 \\
(9)\end{array}$} & Madeline Mary Johnsen Alexander (1921-1979) & Stanford \\
\hline & Grace Elizabeth Bates (1914-1996) & Illinois \\
\hline & Sister Mary Celine Fasenmyer RSM (1906-1996) & Michigan \\
\hline & Margaret Ellen Stump Matchett (1918-2002) & Indiana \\
\hline & Kathryn Ann ("Kay") Morgan (1922-2010) & Stanford \\
\hline & Irma Ruth Moses Reiner (1922-2014) & Cornell \\
\hline & Kathleen E. Butcher ("Kay") Whitehead (1920-2009) & Michigan \\
\hline & Margaret Matilda Young Woodbridge (1904-1995) & NYU \\
\hline & Marie Anna Wurster (1918-2010) & Chicago \\
\hline \multirow{10}{*}{$\begin{array}{c}1947 \\
(10)\end{array}$} & Christine S. Williams Ayoub (1922- ) & Yale \\
\hline & Mary Patricia Dolciani Halloran (1923-1985) & Cornell \\
\hline & Sister Mary Agnes Hatke OSF (1902-1989) & Purdue \\
\hline & Sister Mary Teresine Lewis CSJ (1908-1999) & Catholic \\
\hline & Miriam Amalia Lipschutz-Yevick (1924-2018) & MIT \\
\hline & Mary Anice Seybold (1908-1990) & Illinois \\
\hline & Marianne Ruth Freundlich Smith (1922-2006) & Illinois \\
\hline & Sister M. Francis Borgia Stauder SSND (1911-2012) & Notre Dame \\
\hline & Sister Mary Petronia Van Straten SSND (1913-1987) & Notre Dame \\
\hline & Margaret Frances Willerding (1919-2003) & St. Louis \\
\hline \multirow{10}{*}{$\begin{array}{c}1948 \\
(10)\end{array}$} & Frances Renee Brand Bauer (1923- ) & Brown \\
\hline & Sister Rose Gertrude Calloway CSJ (1909-1992) & Catholic \\
\hline & Yael Naim Dowker (1919-2016) & Harvard/Radcliffe \\
\hline & Evelyn Agnes Fix (1904-1965) & California/Berkeley \\
\hline & Ilse Lisl Novak Gaal (1924- ) & Harvard/Radcliffe \\
\hline & H(elen) Margaret Elliott Larsen (1925-2015) & Harvard/Radcliffe \\
\hline & Mary Ann Lee (1909-1974) & Cornell \\
\hline & Louise Hoy Chin Lim (1922-1985) & California/Berkeley \\
\hline & Julia Bowman Robinson (1919-1985) & California/Berkeley \\
\hline & Jean Brosius Walton (1914-2006) & Pennsylvania \\
\hline \multirow{10}{*}{$\begin{array}{c}1949 \\
(10)\end{array}$} & Anne Marie Whitney Calloway (1921-2008) & Pennsylvania \\
\hline & Jane Smiley Cronin Scanlon (1922-2018) & Michigan \\
\hline & Evelyn Boyd Granville (1924- ) & Yale \\
\hline & L(ois) Aileen Hostinsky (1921-1981) & Illinois \\
\hline & Helen D. Kelsall Nickerson (1918-1990) & Harvard/Radcliffe \\
\hline & Sister Miriam Frances Quinn SBS (1918-1984) & Catholic \\
\hline & Mary Ellen Estill Rudin (1924-2013) & Texas \\
\hline & Esther Seiden (1908-2014) & California/Berkeley \\
\hline & Annette Sinclair (1916-2005) & Illinois \\
\hline & Maria Alice Weber Steinberg (1919-2013) & Cornell \\
\hline
\end{tabular}

